\title{
O Olhar feminino italiano de cinco gerações: da unificação da ltália à queda do Muro de Berlim
}

Mille anni che sto qui.

VENEZIA, Mariolina.

Torino: Einaudi, 2006. 254 p.

Mariolina Venezia nasceu em Matera, na Itália, em 1961, onde viveu sua infância e buscou inspiração para seu primeiro romance. Além de escritora, é também roteirista formada pela Scuola Nazionale di Cinema. Dedica-se ativamente à sétima arte com a criação de documentários, a elaboração de séries para a Radiotelevisione Italiana (RAl) e a colaboração com inúmeras revistas literárias. Após três livros de poesia e uma coletânea de contos intitulada Altri miracoli, obtém significativo reconhecimento da crítica com Mille anni che sto qui.

A inspiração para escrever esse seu romance, objeto desta resenha, remonta a 1990. Nesse ano, a autora filmou o documentário Matera o la memoria rimossa, em que retrata os moradores dos Sassi, habitações escavadas na rocha, que, na ocasião, haviam recebido uma possibilidade de mudança para modernas e cômodas casas populares. Em meio a esse projeto, Mariolina Venezia percebeu que aqueles habitantes representavam um estilo de vida que estaria extinto após suas mortes. E, consequentemente, estaria extinta uma língua, várias expressões e muitas histórias. A partir disso, idealizou o romance, escrito para que a brusca mudança social sofrida pela região evitasse em parte a erradicação dos velhos costumes.

Assim, Mille anni che sto qui nos remete ao sul da Itália, à região da Basilicata, onde começa a ser narrada a saga da família Falcone. Nesse cenário, a autora passeia ciclicamente por cinco gerações, minuciosamente retratadas, desde a unificação do país, em 1861, até a queda do Muro de Berlim, em 1989.

Esse romance, que foi vencedor em 2007 de um dos principais prêmios literários na Itália, o Prêmio Campiello, conquistado no passado por grandes nomes como Antonio Tabucchi, Ignazio Silone e Primo Levi, aborda, com certo realismo fantástico, os fatos vividos pelos habitantes da pequena cidade de Grottole e arredores. O núcleo da narrativa é representado pela família Falcone, mais precisamente pelas mulheres que dela fazem parte. A autora, observada sua condição feminina, quis usar seu ponto de vista dos fatos dando maior voz às mulheres, mostrando-as protagonistas na história. É, pois, um romanzo corale que, reunindo em si mais do que uma voz narradora única para delinear toda a trama, alterna as percepções de cinco mulheres como em um grande proliferar-se de vozes e pensamentos, fazendo com que a ausência de um personagem central principal seja pouco notada.

Cândida é a personagem dona da fala que dá nome ao livro Mille anni che sto qui (p. 244) e, juntamente com as demais mulheres, duas gerações anteriores e duas gerações posteriores, contribuirá para desvelar a mentalidade local. Cândida é neta de Concetta, filha de Albina, mãe de Alba e avó de Gioia. Além delas, verdadeiras protagonistas, há um significativo número de personagens masculinos, contudo serão sempre as percepções femininas da família Falcone que conduzirão o leitor. Assim, torna-se possível penetrar no universo humano que norteia a trama, que evidencia sentimentos como a inveja, a submissão, a miséria, a dor e a aceitação. A formação do indivíduo através de fatos vividos ou perdidos e seus questionamentos pode ser vista desde o início da trama até seus capítulos conclusivos, como, por exemplo, nas percepções acerca do jovem Spiros, desertor grego que a personagem Gioia conhece em suas andanças:

Quante cose può perdere un uomo eppure restare se stesso? Può perdere l'amore, il denaro, la posizione. Una persona cara. La dignità. Può sprecare il suo talento o perdere la sua grande occasione, mancare l'appuntamento al quale si è preparato per tutta la vita. Può perdere $\mathrm{i}$ suoi ideali, i suoi sogni, e alla fine anche la 
memoria. E se un uomo fosse anche questo? Tutte le vite che avrebbe potuto vivere, tutto ciò che ha perso? [Quantas coisas pode perder um homem e, no entanto, permanecer ele mesmo? Pode perder o amor, o dinheiro, a posição. Uma pessoa amada. A dignidade. Pode desperdiçar seu talento, ou perder sua grande oportunidade, faltar ao encontro ao qual se preparara por toda a vida. Pode perder seus ideais, seus sonhos e, no fim, até a memória. E se um homem também fosse isso? Todas as vidas que poderia ter vivido, tudo o que perdeu?] (p. 224).

Depara-se, logo no início do livro, com uma espécie de árvore genealógica feita pela personagem Gioia a pedido da avó Cândida, por esta não se lembrar mais do nome dos pais e dos irmãos. O esboço que, em um primeiro momento, pode não chamar tanto a atenção do leitor revela-se, ao longo da narrativa, uma indispensável ferramenta que o guiará, situandoo apropriadamente na ficção. De fato, a escolha da autora por esse instrumento é bastante pertinente, visto que a história é rica em nomes e traz uma significativa alternação temporal, fazendo com que o presente se repita e assemelhe-se com frequência ao passado.

O ritmo que descreve o então lendário e distante sul é vagaroso, embora se torne repentinamente acelerado à medida que a escritora entra na quarta geração da família. Já na quinta e última geração, as palavras adquirem pulsação irascível, como se houvesse a intenção de transpor um pouco da atmosfera social e política conturbada do fim da década de 1980. Contudo, jogar com o tempo e seu ritmo, passando sem pré-aviso de uma geração à outra, é apenas uma das características marcantes em Mille anni che sto qui.

A presença de situações díspares como a relação entre colonizador e colonizado, existente nos escritos de Allende e García Márquez, por exemplo, é aqui retratada nas figuras do proprietário das terras, Francesco Falcone, e dos que nela trabalham, os cafoni. São realidades separadas pela posse, em que dinheiro não significa, necessariamente, instrução ou esclarecimento.

Apenas com o passar dos anos, alguns habitantes ousam desafiar o destino certo do trabalho na lavoura buscando fortuna na Itália do norte ou tentando "fare l'America". O livro evidencia que, ainda que os destinos de fuga escolhidos pelos personagens sejam diferentes os efeitos para quem imigrava eram iguais: sofriase de fome, cansaço, exaustão, desconforto, além do estranhamento ao inglês e ao não menos "estrangeiro" italiano.

Venezia, que tem como modelo literário Émile Zola, em entrevista concedida ao Jornal L'Unità, de 4 de novembro de 2006, com seu ciclo dos Rougon-Macquart (ainda que este seja composto de vinte romances, sendo-Ihe semelhante pela ideia de pintar um quadro histórico-social), desenha uma trama capaz de entrelaçar fatos individuais da família central do romance a eventos coletivos como a sociedade camponesa, o ingresso no partido comunista e a emigração.

O romance é escrito em italiano standard, contudo apresenta rico vocabulário local e, em algumas ocasiões, busca o léxico dialetal, o que não compromete a leitura por quem não é conhecedor de todos os termos. No início da história, encontrando-se em 1861 e em uma área rural, a autora opta por um vocabulário particularmente associado àquela sociedade, com similitudes e metáforas ligadas ao mundo animal, com o qual a maioria das personagens tinha contato. À medida que o texto cresce, durante o século $X X$, as expressões extraídas do imaginário popular diminuem, fazendo com que a língua perca singeleza, mas ganhe em modernidade e atualidade.

A obra, que mistura poesia e realismo, com toques de ironia que dão leveza à história, ainda não foi traduzida no Brasil, embora outros países, como França, Espanha, Alemanha e Estados Unidos, já a tenham inserido em seu sistema literário. Seria oportuno, aproveitando o ano em que se celebra o momento da Itália no Brasil, que as editoras traduzissem este e outros livros de uma geração de escritoras italianas da atualidade que têm se destacado, como Elvira Seminara e Simona Vinci. Esta seria uma bela oportunidade para estreitarmos os laços já tão antigos, como bem descreveu Sérgio Buarque de Holanda em $A$ contribuição italiana para a formação do Brasil, com este país.

Andréia Guerini
Universidade Federal de Santa Catarina
Stella Rivello
Universidade Federal de Santa Catarina

